\title{
Compendium of plants used for preparation of traditional alcoholic beverages by four major ethnic communities of Assam, northeast India
}

\author{
DIPANKAR BORAH ${ }^{1, \vartheta}$, TRIDIP GOGOI ${ }^{2}$, JINTU SARMA ${ }^{3}$, PUNAM JYOTI BORAH ${ }^{4}$, BICHITRA GOHAIN ${ }^{5}$, \\ CHIRANJIB MILI ${ }^{6}$, ANKUR UPADHYAYA $^{5}$, JENIMA BASUMATARY ${ }^{5}$, KASTURI NEOG $^{5}$, \\ TONLONG WANGPAN ${ }^{5}$, SUMPAM TANGJANG $^{5}$ \\ ${ }^{1}$ Department of Botany, Goalpara College. Goalpara-783101, Assam, India. `email: dipankar.borah@goalparacollege.ac.in \\ ${ }^{2}$ Likson Bohupathar, Badulipar. Golaghat 785611, Assam, India \\ ${ }^{3}$ Department of Botany, Guwahati College. Guwahati 781021, Assam, India \\ ${ }^{4}$ Department of Botany, Cotton University. Guwahati 781001, Assam, India \\ ${ }_{5}^{5}$ Department of Botany, Rajiv Gandhi University. Rono Hills, Doimukh 791112, Arunachal Pradesh, India \\ ${ }^{6}$ Department of Botany, BP Chaliha College. Nagarbera 781127, Assam, India
}

Manuscript received: 1 March 2021. Revision accepted: 27 March 2021.

\begin{abstract}
Borah D, Gogoi T, Sarma J, Borah PJ, Gohain B, Mili C, Upadhyaya A, Basumatary J, Neog K, Wangpan T, Tangjang S. 2021. Compendium of plants used for preparation of traditional alcoholic beverages by different major ethnic communities of Assam, Northeast India. Biodiversitas 22: 2019-2031. This paper deals with the ethnobotanical research on the preparation of traditional alcoholic beverages by Ahom, Bodo, Karbi and Mishing ethnic communities of Assam, India. Along with the information on preparation, the plant species associated with the preparation of alcoholic beverages are also recorded. Field investigations were conducted to cover 32 villages of six districts of Assam, India. The data was generated from 202 respondents using participatory rural appraisal tools including semi-structured questionnaires and personal interviews. The plant species were collected, identified and submitted in the Herbarium of Rajiv Gandhi University, Arunachal Pradesh, India. The study recorded 129 plants falling under 107 genera and 54 families which are exclusively used for the preparation of alcoholic beverages by the studied communities. The study confirmed that the association of traditional alcoholic beverages with their rich indigenous knowledge.. The finding also revealed varied forms of protocol followed by these tribes to prepare traditional liquors and the starter cakes for brewing of alcohol were prepared locally. However, the Mishing tribe was known to prepare unique rice beer known as Po:ro apong, as the preparation technique and extraction process of this liquor was slightly different. Distillation of alcohol was also observed in all the communities except the Ahom. The rich traditional knowledge of brewing alcohol and the plant species used in the process were worth documenting considering the ongoing alteration of traditional society with the modernization.
\end{abstract}

Keywords: Alcoholic beverage, ethnobotany, Northeast India, traditional knowledge, tribal society

\section{INTRODUCTION}

Fermentation and fermented beverages have always been an integral part to human cultures and traditions since ancient times (Alan 1997). The beer is supposed to have originated in Sumeria before 7000 B.C. (Demain et al. 1998). Traditionally prepared fermented beverages have always been associated with the values and survival of the tribes throughout the world since the dawn of civilization (Alan 1997). It is assumed that the preparation of traditional wine, beer and their varieties in consumption may have probably emerged due to the varied climatic conditions and was heavily dependent on the availability and utilization of locally available natural resources (Roy et al. 2004). The fermented rice beverages of the tribal people are prepared using various plants which are known to possess numerous medicinal properties. It has been reported that the phytochemical components present in these plant species proved to have remarkable therapeutic potential when used alone or in combinations (Prakash et al. 2004; Bhuyan and Baishya 2013). These forms of traditional alcoholic beverages have a considerable impact on health care and provide health benefits of preventing and treating gastrointestinal diseases along with certain physiological disorders (Nath et al. 2019) such as insomnia, headache, diarrhea, body ache and inflammation of body parts, expelling worms along with the treatment of cholera and urinary problems (Samati et al. 2007; Deka and Sarma 2010; Nath et al. 2019). Several reports from different parts of Northeast India have also been claimed the presence of nutritional as well as antioxidant properties in rice beer samples which is due to the presence of compounds such as phenolic acids, polyphenols, and flavonoids (Nath et al. 2019).

Assam is home to diverse ethnic communities and tribal groups, mostly of Mongoloid origin, such as Ahom, Rabha, Deori, Tiwa, Bodo, Karbi, Mishing, Sonowal Kachari, etc. (Sharma 2017). These communities have been preparing and consuming traditional rice beer for about 2500 years and possess a good deal of knowledge about fermented food products (Tamang 2010). As such, a variety of cerealbased alcoholic beverages are prepared and consumed by these communities during many occasions such as ritual ceremonies, marriages and merry-making, festivals and 
even death ceremonies (Saikia et al. 2007; Das et al. 2012). The fermentation methods are similar among the ethnic groups with some variations in the preparation of starter cakes which occasionally contain various herbs and rice flour (Das et al. 2012; Das et al. 2019). The current research deals with the ethnobotanical research of important plants used for the preparation of traditional alcoholic beverages by four major ethnic communities (Ahom, Bodo, Karbi, and Mishing) of Assam, India

\section{MATERIALS AND METHODS}

The field study was conducted in six districts of Assam, namely Baksa, Biswanath, Golaghat, Lakhimpur, Sibasagar, and Sonitpur because several ethnic communities reside in these districts (Figure 1), which falls within the upper zone of the state. The boundary of the state extends from $89^{\circ} 42^{\prime} \mathrm{E}$ to $96^{\circ} \mathrm{E}$ longitudes and $24^{\circ} 8^{\prime}$ $\mathrm{N}$ to $28^{\circ} 2^{\prime} \mathrm{N}$ latitudes and covers an area of $78,438 \mathrm{~km} 2$. The elevation ranges from 45 to 1,960 meters above mean sea level and the temperature from $35-38^{\circ} \mathrm{C}\left(95-100{ }^{\circ} \mathrm{F}\right)$ during summers and $6-8^{\circ} \mathrm{C}\left(43-46^{\circ} \mathrm{F}\right)$ during winters. It has a mean annual rainfall of $1,524.6 \mathrm{~mm}$. The present population is 31 million and the literacy rate is $72.19 \%$ (Census 2011).

Field investigations were conducted from October 2019 to March 2020 to cover thirty two villages of six districts of Assam, India. Selection of respondents was done through purposive stratified sampling from those villagers who accepted the request for an interview voluntarily. A total of 202 respondents (i.e., mostly age-old folks and women), present in these villages were selected for data collection. Data was collected through interviews by various participatory rural appraisal tools such as semi-structured questionnaires and personal interviews. Collection of plant species was done in the presence of respondents and was later processed following the methods of Jain and Rao (1976). It was then identified using relevant literatures (Hooker 1897; Kanjilal et al. 1934-1940), and consulting voucher specimens present in regional herbaria (ARUN, ASSAM) and submitted in Herbarium of Rajiv Gandhi University, Arunachal Pradesh, India.

\section{MAP OF ASSAM}

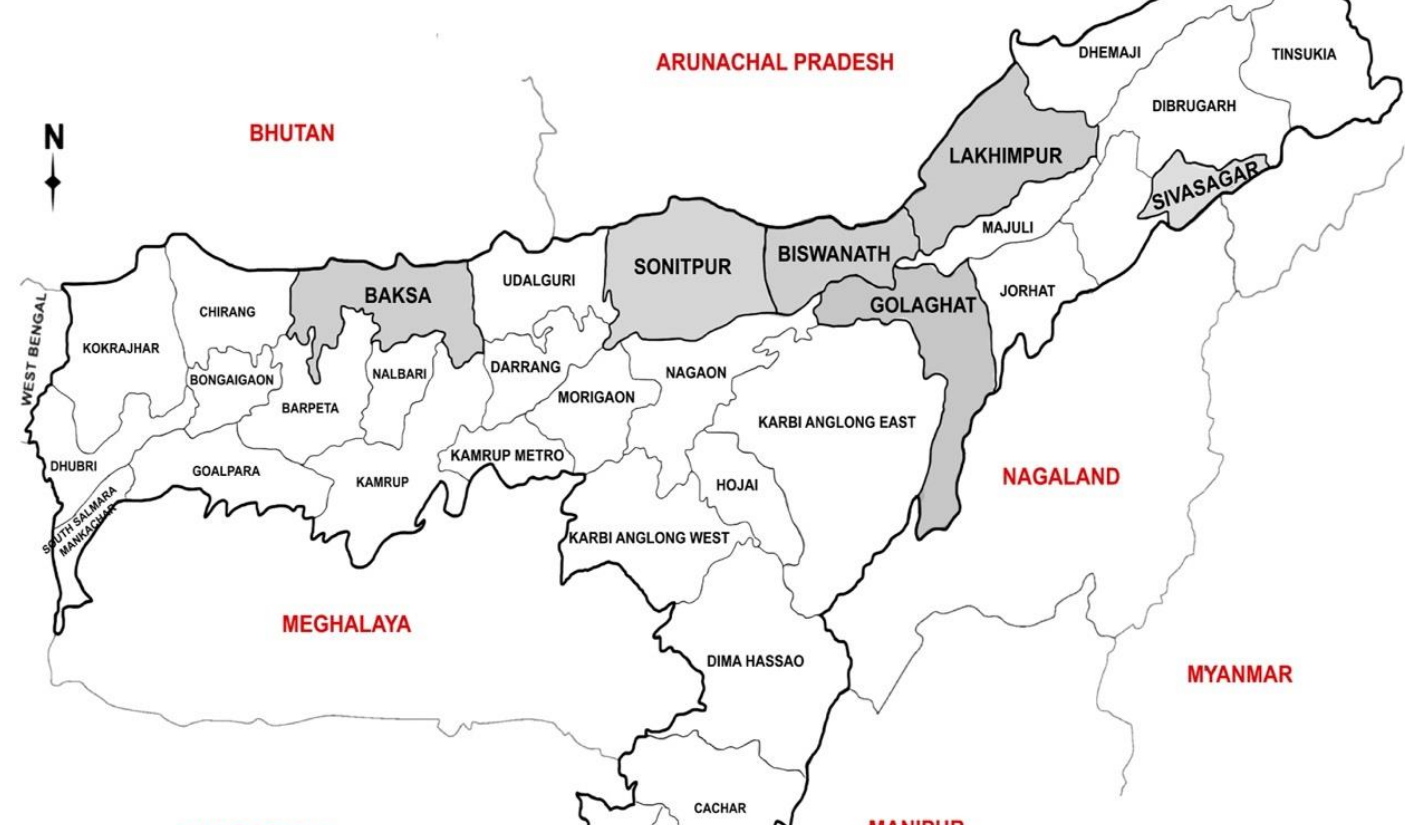

BANGLADESH

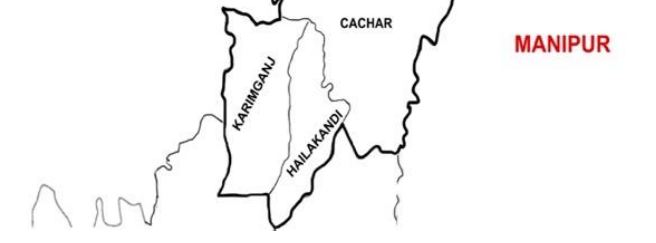

STUDY AREA

MAP IS NOT TO SCALE

Figure 1. Map of Assam showing study area, i.e. 6 districts of Assam, India 


\section{RESULTS AND DISCUSSION}

The study reported a total of 129 plants falling under 107 genera and 54 families used by four major ethnic communities of Assam used for the preparation of traditional alcoholic beverages (Table S1). Among the 54 families, Lamiaceae and Lauraceae were the most dominant families with eight species each, followed by Asteraceae (7 spp.), Rubiaceae and Polygonaceae with 6 spp. each (Table 3). Leaf (88\%) is the most commonly used plant part, followed by twig $(4 \%)$ and root $(3 \%)$ (Figure 2). A brief pictorial account of traditional alcoholic beverages prepared by major ethnic communities Ahom, Bodo, Karbi and Mishing of Assam is depicted in Figure 3.

Table 2. Traditional alcoholic beverages of major tribal communities residing in Assam

\begin{tabular}{lcc}
\hline Community & Alcoholic-beverage & Starter culture \\
\hline Ahom & Haaj, Laupani & Haajpitha, Vekurpitha \\
Bodo & Jou, Bishi & Amao, Angkur \\
Karbi & Hor/Hor-alank & Thap \\
Mishing & Poro apong, Sai mod & Apoppitha \\
\hline
\end{tabular}

Table 3. Table showing ten dominant families of plants used in preparation of traditional alcoholic beverages in Assam, India

\begin{tabular}{lc}
\hline \multicolumn{1}{c}{ Family } & Number of species \\
\hline Asteraceae & 7 \\
Fabaceae & 5 \\
Lamiaceae & 8 \\
Lauraceae & 8 \\
Moraceae & 4 \\
Piperaceae & 5 \\
Poaceae & 4 \\
Polygonaceae & 6 \\
Rubiaceae & 6 \\
Solanaceae & 5 \\
\hline
\end{tabular}

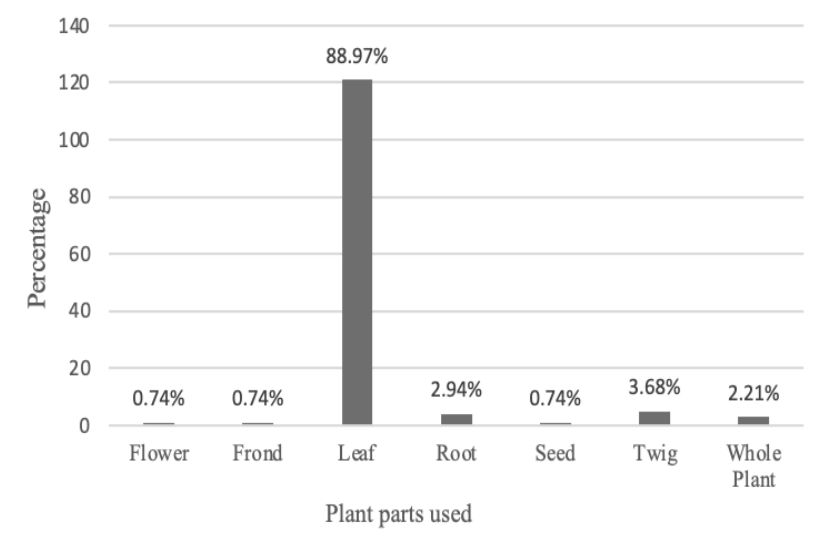

Figure 2. Bar diagram showing the percentage of plants parts used in preparation of traditional alcoholic beverages in Assam, India

\section{Preparation of starter cakes}

The preparation of starter cakes usually begins with the collection of various plants which add to the starter cakes and are believed to add certain flavor/medicinal value/ nutrients to it (Figure 5). The collected plant parts were washed properly and used in either fresh form or dried. Drying was done under smoke or sun for a couple of days. At the same time, rice grains were soaked in water for about 2 to 6 hours and then rinsed to drain out the excess water and ground into powder. The dried plant parts are also grounded separately and mixed with the powdered rice. Subsequently, the dough was prepared, adding a small amount of finely powdered previously prepared starter cake (which serves as inoculants). Small-sized round balls were prepared from the dough, which is then dried and stored above the fireplace until further use. Dried leaves of Thelypteris parasitica (L.) Tardieu, Musa balbisiana Colla, and paddy hay were used to keep the starter balls free from harmful pests and moisture and increase the longevity of the product. The starter cakes and alcoholic beverages acquired different names in different tribal dialects (Table 2).

\section{Preparation of rice beer}

Traditional rice beer is usually prepared by fermenting boiled rice mixed with starter cakes (Figure 5). The process starts with the boiling of rice (preferably glutinous varieties). The cooked rice was then spread on banana leaves placed in a winnowing basket and allowed to cool to room temperature. The powdered starter cakes were mixed with the boiled rice and filled in an earthen pot or any vessel, and sealed with banana or Alpinia leaves, straw and a piece of clean cloth. The incubation period of fermentation varied from 5-9 days depending on the season and the climate of the region. After the incubation period, the mixture was taken out and filtered to separate the alcoholic liquid from the fermented rice. The filtered liquid or rice beer is now ready for consumption. Several tribal nomenclatures of rice beer and the materials used are mentioned in Table 2.

\section{Preparation of Po:ro apong}

It is worth mentioning that the process of rice beer preparation of all the studied tribes of Assam (Ahom, Mishing, Bodo, and Karbi) was more or less similar, differing only in the plants used (Table S1). But the Mishing tribe is known to prepare an additional unique rice beer known as Po:ro apong. The preparation technique, as well as extraction process of this alcoholic beverage, was slightly different from its counterparts (Figure 6). To prepare this beverage, paddy husk and dried paddy straw were partially burnt to collect the ash in a separate container. The collected ash along with the powdered starter cake was mixed along with the boiled rice. The mixture was then added to an earthen pot (severely fumigated pot, turning its color into blackish) and the mouth was sealed with the help of straw and leaves of Thelypteris parasitica (L.) Tardieu. The fermentation usually takes a week or two (depending on the season of preparation, warmer the climate faster the fermentation process or vice versa, and amount of starter used). 

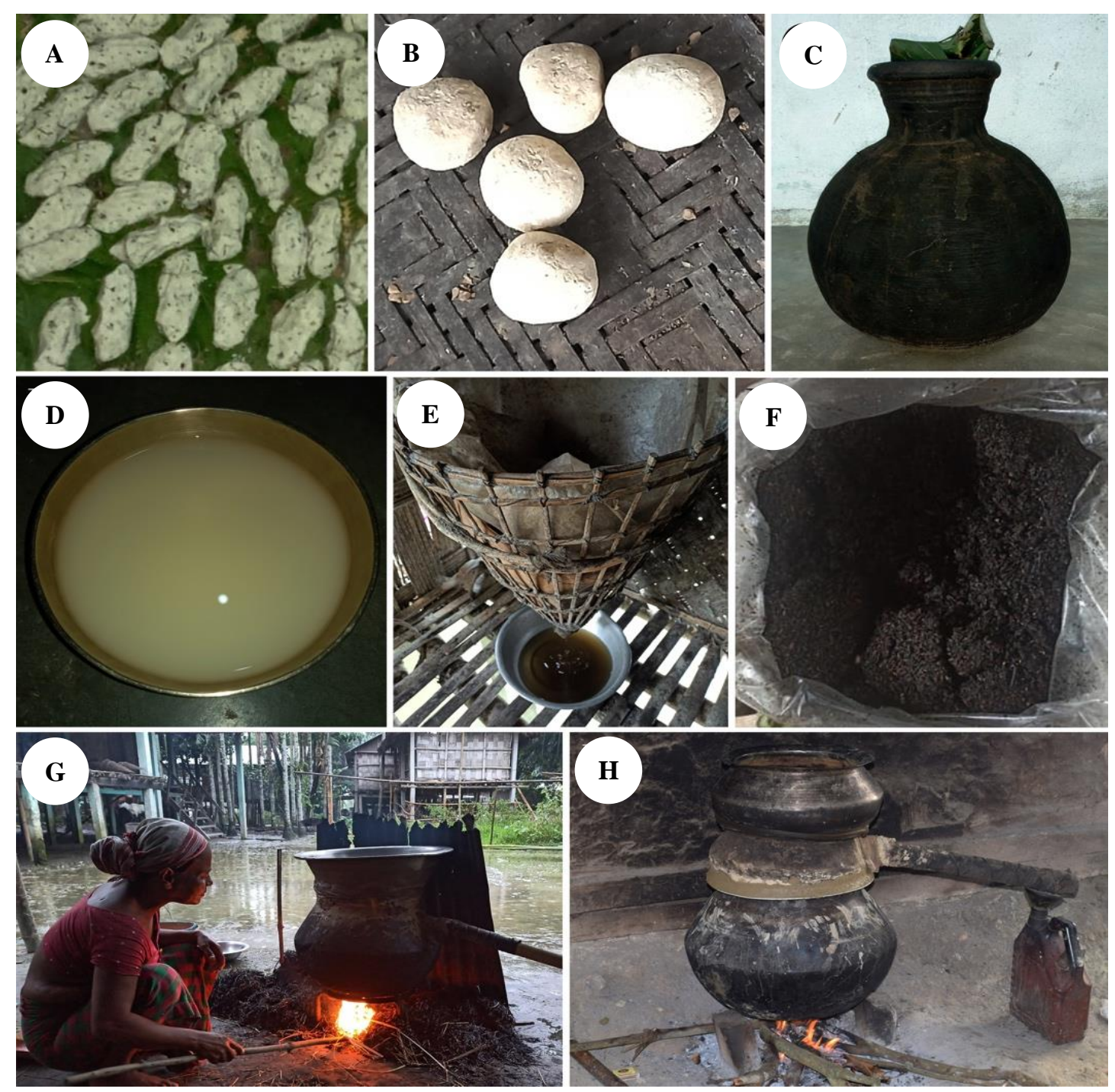

Figure 3. Traditional alcoholic beverages of Assam: A-B. Starter cakes, C. Vessel for rice beer preparation, D. Rice beer (Xaajpani of Ahom), E. Po-ro apong filtration unit, F. The mixture of Po-ro apong, G-H. Distilled alcohol distillation unit

For the extraction of liquid, the cone-shaped bamboo basket called Ta:suk was hung from a post. The interior walls of the bamboo basket were covered with banana leaves. A pack of paddy straw (Amrong) was placed at the base of the bamboo basket which serves as a sieve for filtration. The prepared fermented mixture (boiled rice + ash) was then poured inside the Ta:suk and warm water were poured from above which usually extracts the soluble components of the rice beer including alcohol. Coldwater is poured at first, to cool the fermented mixture, then hot water is slowly poured, sequentially, however, the filtrate remains cool for the first batches, until the filtrate turns hot, then the process is stopped. The filtrate (Apong) was then collected in a container placed just below the bamboo basket. But excess addition of water is not advised as it is believed to decrease the intoxicating effect as well as the sweetness of the beverage. Nevertheless, the production of Po:ro apong is considered to be a tedious process; thus, it is usually prepared in case of large and important community gatherings such as festivals, rituals and other cultural gatherings.

\section{Preparation of distilled alcohol}

The distillation of alcohol was observed among the three studied communities except for the Ahoms (Figure 7). For distillation, the fermented rice beer was diluted by adding water and stored for some time. At the same time, the distillation process can be carried out either at the early stage of rice beer preparation or after harvesting of rice beer. The complete process of distillation may take 4 hours. The quality of alcohol is strong if prepared before harvesting rice beer by adding more amounts of starter cakes, or by adding less water while diluting.

The traditional distillation apparatus has three different chambers which consist of: (i) The lower chamber consists of a metallic utensil containing diluted fermented rice beer. (ii) The middle chamber consists of an earthen pot with a perforated base. It also has a small bowl over the 
perforation, inside the pot which acts as a receiver to contain the distilled alcohol. In certain cases, the earthen pot was also found to be fitted with a long bamboo cylindrical tube on the side of the pot, which permits the flow of the distilled alcohol outside of the apparatus. The distilled alcohol is collected in a utensil placed at the end of the cylindrical tube. (iii) The upper chamber entails a metallic utensil, filled with cold water which acts as a condenser.

To prevent the leakage of vapors from the apparatus, the gap between the utensils was sealed with a moist muslin cloth, mud or with the residue of rice beer.

On constant heating, the filtered rice beer in the lowermost utensil forms vapor, passes through the perforated base of the middle compartment before hitting the base of the condenser, after which it settles down and collected by the bowl placed above the perforation, or through the tube directly into a bottle. The water of the condenser was repeatedly replaced so that the condensation continues. The more the alcohol is distilled, the less is the concentration.

The study unveiled the association of traditional alcoholic beverages with the rich indigenous knowledge system of the region. The finding also revealed the varied forms of protocol followed by different tribes of Assam for the preparation of traditional liquors. The starter culture was usually used as a source of yeast strains in the fermentation process. Also, they included various plant species in preparation for starter culture. Such starter culture usually persists for several months at room temperature and in a dry place (Tamang and Sarkar 1998).

There are several pieces of literature mentioned in Table S1 (last column) that corroborate the current findings. Thus, total 39 plants from our record were already reported by previous workers. While, a total of 90 plant species were newly recorded among the Ahom, Mishing, Bodo and Karbi for the preparation of traditional alcoholic beverages. Also, the most commonly added plants were Ananas comosus (L.) Merr., Capsicum annuum L., Centella asiatica (L.) Urb., Clerodendrum infortunatum L., Lygodium flexuosum (L.) Sw., Oryza sativa L., Piper nigrum L., Saccharum officinarum L.and Scoparia dulcis L.. The neighboring Northeastern states of India also retain their unique way of brewing alcohol. For instance, the addition of leaf extracts of Clerodendrum viscosum Vent. (synonym of Clerodendrum infortunatum L.) and Calotropis gigantea (L.) W.T.Aiton to rice, millet and corn to prepare beers in Sikkim (Tsuyoshi et al. 2005). Production of fermented spirit from rice called $U$ Phandieng and cocktail of millet and rice beer called KaKiad among the Khasis of Meghalaya (Ahmed and Borthakur 2005). Addition of extract of tree barks and fern leaves to rice beer by Meithei tribe of Manipur (Hodson 1999). Germinated rice grains are mixed with powdered rice to produce Peyazu by Angamis of Nagaland (Sharma et al. 2019). The addition of ash and extracts of Eleusine coracana (L.) Gaertn. and Saurauia roxburghii Wall. to the broth containing dried or boiled millet or rice and starter yeast powder (called epo) by the Apatani tribe of Arunachal Pradesh (Tanti et al. 2010).

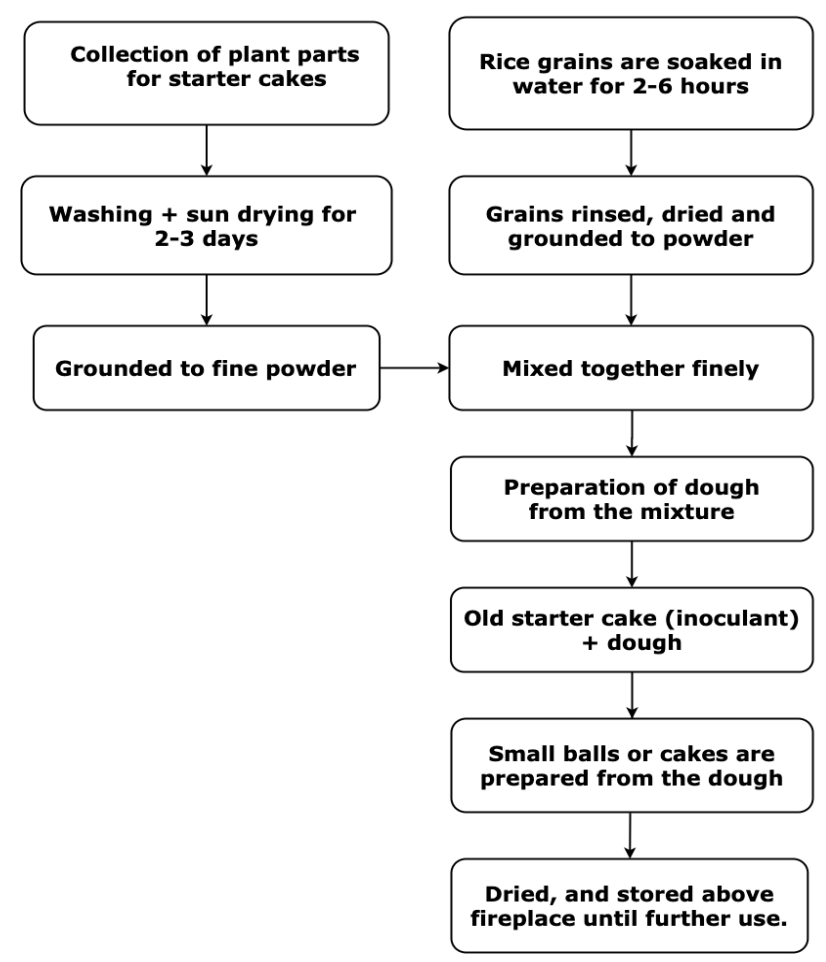

Figure 4. Steps for preparation of starter cakes by tribal communities of Assam, India

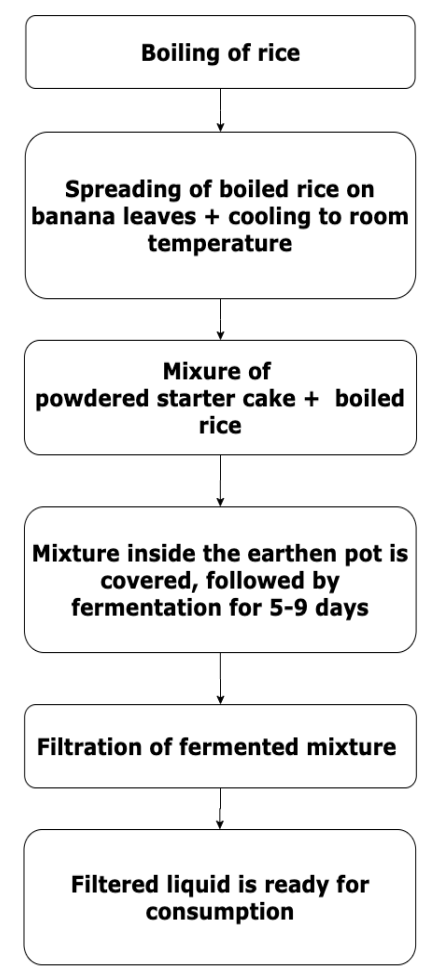

Figure 5. Steps for preparation of rice beer by tribal communities of Assam, India 


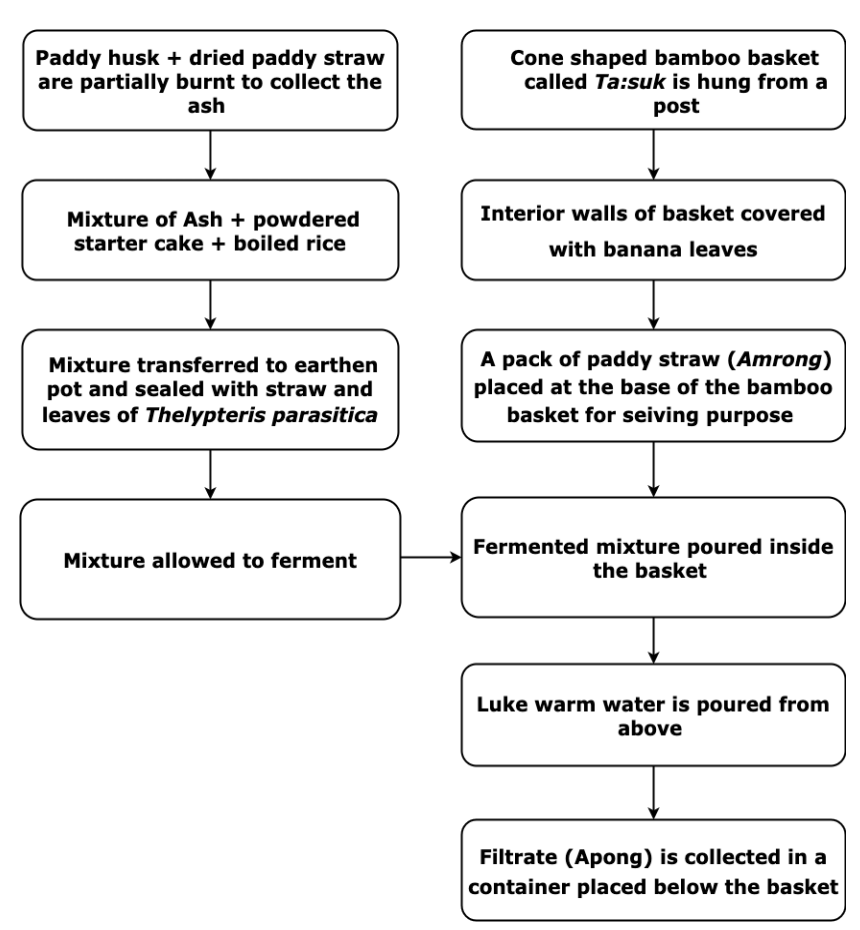

Figure 6. Steps for preparation of Po:ro apong by Mishing community of Assam, India

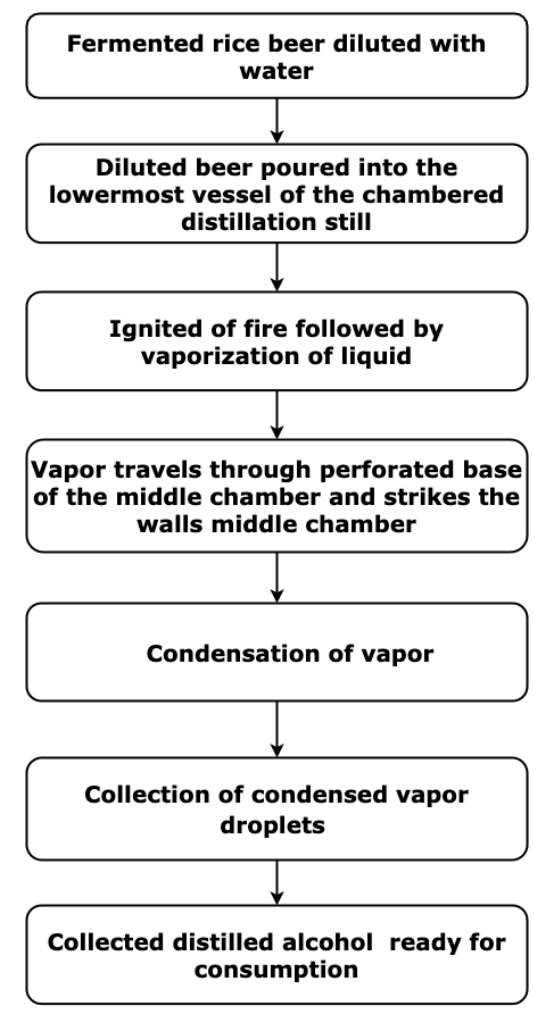

Figure 7. Steps for preparation of distilled alcohol by tribal communities of Assam, India.
Our findings assumed that the process of distillation of alcohol which was executed by the three studied tribes of Assam was almost similar. Likewise, in other parts of India, such distilled alcoholic liquor is very commonly consumed, such as $Y u$ angouba of Manipur (Singh and Singh 2006), Chulli of Himachal Pradesh (Thakur and Savitri 2004), fenny of Goa (Nayak and Prabhu 2013), Mahua of Central India (Yadav et al. 2009), Mahuli from Orissa (Behera et al. 2016), Soor from Uttarakhand and Himachal Pradesh (Rana et al. 2004) and Chhang of Western Himalayan region (Ahuja et al. 2014), etc.

In conclusion, the rich traditional knowledge of brewing alcohol and the plant species used in the process were worth documenting considering the alteration of traditional society with the modernization. Also, considering the on-going rapid industrialization, the successful relocation of the traditional beverages from the household to the industrial-scale production with improved quality from a microbiological stance may stimulate the rural economy.

\section{ACKNOWLEDGEMENTS}

We are indebted to all the tribal communities for sharing their valuable knowledge. The authors are also grateful to Dakeswari Mili, Purna Tokbi for their help in the collection of field data. We are also thankful to Lt. Hadhori Barukial (Anai), Lt. Numoli Barukial Gogoi, Lt. Sornalata Gogoi, Lt. Gunada Phukan, Gunomai Gogoi, and Baputi Borah for their immense help. Lastly, we duly acknowledge the instructive comments provided by the reviewers which improved the quality of the manuscript.

\section{REFERENCES}

Ahmed AA, Borthakur SK. 2005. Ethnobotanical wisdom of Khasis of Meghalaya. Bishen Singh Mahendra Pal Singh, DehraDun.

Ahuja U, Ahuja SC. 2014. Alcoholic Rice Beverages. In: Selin H. (Eds.) Encyclopedia of the History of Science, Technology and Medicine in Non-Western Cultures. Springer, Dordrecht.

Alan RE. 1997. Guidelines for Environmental Assessments and Traditional Knowledge. A Report from the Centre for Traditional Knowledge to the World Council of Indigenous People. Environment Canada, Canada.

Arjun J, Verma AK, Prasad SB. 2014. Method of preparation and biochemical analysis of local tribal wine Judima: An indigenous alcohol used by Dimasa tribe of North Cachar Hills. Intl Food Res J 21 (2): 463-470.

Baruah A, Gohain K, Sonowal J. 2010. Plants used in the preparation of starter culture of rice-beer by the Ahom, Deori and Mishing tribes of Dhemaji district, Assam, India. Pleione 4 (2): 288-293.

Basumatary M, Gogoi M. 2014. A traditional alcoholic beverage Jo: Prepared by Bodo community of Assam, India. Int J Multidiscip Res Dev 1 (7): 307-313.

Basumatary TK, Terangpi R, Brahma C, Roy P, Boro H, Narzary H, Daimary R, Medhi S, Brahma BK, Brahma S, Islary A, Swargiary SS, Das S, Begum RH, Bose S. 2014. Jou: The traditional drink of the Boro tribe of Assam and North East India. J Sci Innov Res 3 (2): 239243.

Behera S, Ray RC, Swain MR, Mohanty RC, Biswal AK. 2016. Traditional and current knowledge on the utilization of mahua (Madhucalatifolia L.) flowers by the santhal tribe in similipal biosphere reserve, Odisha, India. Annals Trop Res 38 (1): 94-104. DOI: $10.32945 / a t r 3818.2016$ 
Bhuyan B, Baishya K. 2013. Ethnomedicinal values of various plants used in the preparation of traditional rice beer by different tribes of Assam. Drug Invent Today 5 (4): 335-341. DOI: 10.1016/j.dit.2013.09.002

Bhuyan B, Rajak P. 2019. Natural beverages of Assam and its ethnomedicinal value. In: Grumezescu A, Holban AM. Natural beverages: Volume 13: The science of beverages. Academic Press.

Brahma S, Narzary H, Brahma J. 2014. Socio-cultural and religious plants used by Bodo tribes of BTC, Assam, India. Int J Sci Res Pub 4 (1): 111.

Census. 2011. Directorate of Economics and Statistics. Accessed at (https://des.assam.gov.in/information-services/state-profile-of-assam).

Das A, Deka S, Miyaji T. 2012. Methodology of rice beer preparation and various plant materials used in starter culture preparation by some tribal communities of North-East India: A survey. Int Food Res J 19: 101-107.

Das A. 2016. Medicinal plants used traditionally for the preparation of rice beer by the Tiwa tribe of Morigaon district of Assam, India. Int J Curr Res 8 (11): 40940-40943.

Das AJ, Deka DC. 2012. Mini-review fermented foods and beverages of the North-East India. Intl Food Res J 19 (2): 377-392.

Das AK, Hazarika M. 2015. Study of diversity of ethnobotanical plants used by the Mishing tribes of Golaghat district, Assam and their conservation. Int J Recent Sci Res 6 (7): 4992-4998.

Das S, Deb D, Adak A, Khan MR. 2019. Exploring the microbiota and metabolites of traditional rice beer varieties of Assam and thei functionalities. 3 Biotech 9: 174. DOI: 10.1007/s13205-019-1702-z

Deka D, Sarma GC. 2010. Traditionally used herbs in the preparation of rice-beer by the Rabha tribe of Goalpara district, Assam. Ind J Trad Knowl 9 (3): 459-462.

Demain AL, Phaff HJ, Kurtzman CP. 1998. The industrial and agricultural significance of yeasts. In: Kurtzman CP, Fell JW. (Eds). The Yeasts a Taxonomic Study, 4th Edition, Elsevier, Amsterdam.

Deori C, Begum S, Mao AA. 2007. Ethnobotany of Sujen-A local rice beer of Deori tribe of Assam. Ind J Trad Knowl 6 (1): 121-125.

Gogoi B, Dutta M, Mondal P. 2013. Various ethnomedicinal plants used in the preparation of Apong, a traditional beverage use by Mising tribe of upper Assam. J Appl Pharm Sci 3 (4): 85-88. DOI: 10.7324/JAPS.2013.34.S16

Goswami N. 2020. Traditional rice beer of the Tiwa community: An analytical exposition. Int J Sci Technol Res 9 (3): 6265-6268.

Handique P, Deka DC. 2016. Methodology of rice beer preparation by some ethnic communities residing in Sivasagar District of Assam, India: A survey. Int J Multidis Res Dev 3 (1): 337-340.

Hodson TC. 1999. The Meitheis. LPS Publications, New Delhi.

Hooker JD. 1897. The Flora of British India. I-VII. L. Reeve and Company, London, England.

Jain SK, Rao RR. 1976. A Handbook of Field and Herbarium Methods. Today and Tomorrow's Printers and Publishers, New Delhi.

Kanjilal VN, Kanjilal PC, Das A, De RN, Bor NL. 1934-1940. Flora of Assam, I-V. Government Press, Shillong, India.

Kardong D, Deori K, Sood K, Yadav RNS, Bora TC, Gogoi BK. 2012. Evaluation of nutritional and biochemical aspects of Po:ro apong- (saimod)-a homemade alcoholic rice beverage of Mishing tribe of Assam, India. Ind J Trad Knowl 11 (3): 499-504.

Nath N, Ghosh S, Rahaman L, Kaipeng DL, Sharma BK. 2019. An overview of traditional rice beer of North-east India: Ethnic preparation, challenges and prospects. Ind J Trad Knowl 18: 744-757.

Nayak NP, Prabhu NBM. 2013. A study on alcohol consumption patterns and preference of liquor over wine amongst the youth in Manipal. J Hospit Tour 1 (1): 77-88

Pawe D, Gogoi R. 2013. Ethnobotany of Poro Apong or Chai mod- a local rice beer of Mishing tribes of Assam. NeBio 4 (2): 46-49.

Prakash D, Dhakare R, Mishra A. 2004. Carotenoids: The phytochemicals of nutraceutical importance. Ind J Agric Biochem 17: 1-8.

Rana TS, Datt B, Rao RR. 2004. Soor: A traditional alcoholic beverage in Tons Valley, Garhwal Himalaya. Ind J Trad Knowl 3 (1): 66-71.

Roy B, Kala CP, Farooquee NA, Majila BS. 2004. Indigenous fermented food and beverages: A potential for economic development of the high altitude societies in Uttaranchal. J Hum Ecol 15: 45-49.

Saikia B, Tag H, Das AK. 2007. Ethnobotany of food and beverages among the rural farmers of Tai Ahom of North Lakhimpur district, Assam. Ind J Trad Knowl 6 (1): 126-132.

Samati H, Begam SS, Kiad. 2007. A popular local liquor of Pnar tribe of Jaintia hills district, Meghalaya. Ind J Trad Knowl 6: 133-135.

Senapati SS, Gurumayum S. 2016. Medicinal plants used in traditional alcoholic beverage preparation by tribes of Assam. Res J Pharm Biol Chem Sci 7 (5): 1048-1061.

Sharma BK, Nath N, Ghosh S, Rahaman L, Kaipeng DL. 2019. An overview of traditional rice beer of North-east India: Ethnic preparation, challenges and prospects. Ind J Trad Knowl 18 (4): 744757.

Sharma R. 2017. Rice Beer and tribes of Assam. J Hum Soc Sci 22 (7): 13-16. DOI: $10.9790 / 0837-2207021316$

Singh PK, Singh KI. 2006. Traditional alcoholic beverage, Yu of Meitei communities of Manipur. Ind J Trad Knowl 5 (2): 184-190.

Tamang J P. 2010. Himalayan Fermented Foods: Microbiology, Nutrition and Ethnic value. CRC Press, Taylor and Francis Group, USA, New York.

Tamang JP, Sarkar PK, Hesseltine CW. 1988. Traditional fermented foods and beverages of Darjeeling and Sikkim- a review. J Sci Food Agric 44: 375-385. DOI: 10.1002/jsfa.2740440410

Tanti B, Gurung L, Sarma H, Buragohain A. 2010. Ethnobotany of starter cultures used in alcohol fermentation by a few ethnic tribes of Northeast India. Ind J Trad Knowl 9 (3): 463-466.

Teron R. 2006. Hor, the traditional alcoholic beverage of Karbi tribe in Assam. Nat Prod Radiance 5 (5): 377-381.

Thakur N, Savitri, Bhalla TC. 2004. Characterization of some traditional fermented foods and beverages of Himachal Pradesh. Ind J Trad Knowl 3 (3): 325-335.

Tsuyoshi N, Fudou R, Yamanaka S, Kozaki M, Tamang N, Thapa S, Tamang JP. 2005. Identification of yeast strains isolated from Marcha in Sikkim, a microbial starter for amylolytic fermentation. Int J Food Microbiol 99 (2): 135-146. DOI: 10.1016/j.ijfoodmicro.2004.08.011.

Yadav P, Garg N, Dwivedi D. 2009. Preparation and evaluation of Mahua (Bassia latifolia) Vermouth. Int J Food Ferment Technol 2 (1): 57-61. 
BIODIVERSITAS

Volume 22, Number 4, April 202

Pages: 2019-2031
ISSN: 1412-033X

E-ISSN: 2085-4722

DOI: 10.13057/biodiv/d220451

Table S1. Plants used for the preparation of traditional alcoholic beverages by major ethnic communities of Assam: Parts used and previous records. Note: Ah, A= Ahom; Mi, M=Mishing, Bo, $\mathrm{B}=$ Bodo and $\mathrm{Ka}, \mathrm{Ga}, \mathrm{G}=$ Karbi

\begin{tabular}{|c|c|c|c|c|c|c|}
\hline $\begin{array}{c}\text { Tribal } \\
\text { community }\end{array}$ & Updated name & Family & Local name & $\begin{array}{c}\text { Parts } \\
\text { used }\end{array}$ & $\begin{array}{c}\text { Collection } \\
\text { number }\end{array}$ & Previous records \\
\hline $\mathrm{Ah}$ & Achyranthes aspera $\mathrm{L}$. & Amaranthaceae & Uvotahoth (A) & Leaf & TG 1078 & - \\
\hline $\mathrm{Ah}$ & Acmella oleracea (L.) R.K. Jansen & Asteraceae & Huhoni bon (A) & Leaf & TG 1079 & - \\
\hline $\mathrm{Ah}$ & $\begin{array}{l}\text { Acmella paniculata (Wall. ex DC.) } \\
\text { R.K. Jansen }\end{array}$ & Asteraceae & Huhoni bon (A) & Leaf & PB 1039 & - \\
\hline $\mathrm{Ah}$ & Actinodaphne sp. & Lauraceae & Baghnola pat (A) & Leaf & TG 1080 & - \\
\hline $\mathrm{Ah}$ & $\begin{array}{l}\text { Alternanthera sessilis (L) R. Br. ex } \\
\text { DC. }\end{array}$ & Amaranthaceae & Matikaduri (A) & Leaf & PB 1043 & $\begin{array}{l}\text { Deori et al. 2007; Senapati and Gurumayum 2016; } \\
\text { Bhuyan and Rajak } 2019\end{array}$ \\
\hline $\mathrm{Ah}$ & Amaranthus viridis $\mathrm{L}$. & Amaranthaceae & Khutura (A) & Leaf & PB 1059 & - \\
\hline Ah, Bo & Ananas comosus (L.) Merr. & Bromeliaceae & $\begin{array}{l}\text { Anarokh/Mati-kathal (A), } \\
\text { Rwimali (B) }\end{array}$ & Leaf & $\begin{array}{l}\text { BG 003; PB } \\
\text { 1073; JB 027; TG } \\
1082\end{array}$ & - \\
\hline $\mathrm{Ah}$ & $\begin{array}{l}\text { Aporosa octandra (Buch.-Ham. ex } \\
\text { D.Don) Vickery }\end{array}$ & Phyllanthaceae & Khokoraheloch (A) & Leaf & TG 1142 & - \\
\hline $\mathrm{Ah}$ & Ardisia solanacea Roxb. & Primulaceae & Tuluthapoka (A) & Leaf & TG 1083 & - \\
\hline $\mathrm{Ah}$ & Argyreia nervosa (Burm.f.) Bojer & Convolvulaceae & $\begin{array}{l}\text { Bridhodaroklota/Hunporuah } \\
\text { lota/ Tukoriyaalu (A) }\end{array}$ & Leaf & TG 1143 & - \\
\hline $\mathrm{Ah}$ & Artocarpus chama Buch.-Ham. & Moraceae & Sam kathal (A) & Leaf & TG 1085 & - \\
\hline Ah, Mi, Bo & Artocarpus heterophyllus Lam. & Moraceae & $\begin{array}{l}\text { Belang (M), Kothal (A), } \\
\text { Khatol/ Khanthal (B) }\end{array}$ & Leaf & $\begin{array}{l}\text { CM 108; BG 002; } \\
\text { PB 1030; JS } \\
\text { 2346; JB 021; TG } \\
1084\end{array}$ & $\begin{array}{l}\text { Baruah et al. 2010; Deka and Sarma 2010; Bhuyan and } \\
\text { Baishya 2013; Gogoi et al. 2013; Pawe and Gogoi 2013; } \\
\text { Basumatary et al. 2014; Basumatary and Gogoi 2014; } \\
\text { Senapati and Gurumayum 2016; Das 2016; Bhuyan and } \\
\text { Rajak } 2019\end{array}$ \\
\hline $\mathrm{Ah}$ & Averrhoa carambola $\mathrm{L}$. & Oxalidaceae & Kordoi (A) & Leaf & PB 1056 & - \\
\hline $\mathrm{Ah}$ & Bambusa tulda Roxb. & Poaceae & Baah pat (A) & Leaf & $\begin{array}{l}\text { PB 1071; TG } \\
1086\end{array}$ & - \\
\hline $\mathrm{Ah}$ & Bonnaya ciliata (Colsm.) Spreng. & Linderniaceae & $\begin{array}{l}\text { Kasidaria/ Horukasi-doriya } \\
\text { (A) }\end{array}$ & Leaf & $\begin{array}{l}\text { PB 1057; TG } \\
1145\end{array}$ & - \\
\hline $\mathrm{Ah}$ & $\begin{array}{l}\text { Bonnaya ruellioides (Colsm.) } \\
\text { Spreng. }\end{array}$ & Linderniaceae & Bor kasi-doriya (A) & Leaf & TG 1146 & - \\
\hline $\mathrm{Ah}$ & Callicarpa arborea Roxb. & Lamiaceae & Tangloti (A) & Leaf & TG 1087 & - \\
\hline $\mathrm{Ah}$ & Callicarpa longifolia Lam. & Lamiaceae & Gorokhiyakorai (A) & Leaf & TG 1088 & - \\
\hline $\mathrm{Ah}$ & Cannabis sativa $\mathrm{L}$. & Cannabaceae & Bhang gos (A) & Leaf & PB 1068 & - \\
\hline $\mathrm{Ah}$ & Capsicum аппиит $\mathrm{L}$. & Solanaceae & Jolokia (A) & Leaf & TG 1089 & $\begin{array}{l}\text { Baruah et al. 2010; Deka and Sarma 2010; Pawe and } \\
\text { Gogoi 2013; Gogoi et al. 2013; Bhuyan and Baishya } \\
\text { 2013; Basumatary et al. 2014; Das and Hazarika 2015; } \\
\text { Senapati and Gurumayum 2016; Bhuyan and Rajak } 2019\end{array}$ \\
\hline $\mathrm{Mi}$ & Capsicum frutescens $\mathrm{L}$. & Solanaceae & Mirsi (M) & Leaf & CM 111 & - \\
\hline
\end{tabular}


BORAH et al. - Compendium of plants used for preparation of traditional alcoholic beverages

\begin{tabular}{|c|c|c|c|c|c|c|}
\hline $\mathrm{Ah}$ & Centella asiatica (L.) Urb. & Apiaceae & Bor mani-muni (A) & $\begin{array}{l}\text { Whole } \\
\text { plant }\end{array}$ & BG 004; TG 1090 & $\begin{array}{l}\text { Deori et al. 2007; Baruah et al. 2010; Das et al. 2012; } \\
\text { Kardong et al. 2012; Gogoi et al. 2013; Pawe and Gogoi } \\
\text { 2013; Bhuyan and Baishya 2013; Senapati and } \\
\text { Gurumayum 2016; Handique and Deka 2016; Bhuyan } \\
\text { and Rajak 2019; Nath et al. } 2019\end{array}$ \\
\hline $\mathrm{Ah}$ & Chloranthus elatior Link & Chloranthaceae & Gathikaliya (A) & Leaf & TG 1147 & - \\
\hline $\mathrm{Ah}$ & $\begin{array}{l}\text { Cinnamomum bejolghota (Buch.- } \\
\text { Ham.) Sweet }\end{array}$ & Lauraceae & Patihunda/Naga dalseni (A) & Leaf & TG 1148 & - \\
\hline $\mathrm{Ah}$ & $\begin{array}{l}\text { Cinnamomum tamala (Buch.- } \\
\text { Ham.) T.Nees \& C.H.Eberm }\end{array}$ & Lauraceae & Tezpat (A) & Leaf & PB 1074 & $\begin{array}{l}\text { Baruah et al. 2010; Gogoi et al. 2013; Senapati and } \\
\text { Gurumayum } 2016\end{array}$ \\
\hline $\mathrm{Ah}$ & Cinnaтотит verum J.Presl & Lauraceae & Dalseni pat (A) & Leaf & TG 1091 & - \\
\hline $\mathrm{Ah}$ & Cissampelos pareira $\mathrm{L}$. & Menispermaceae & Bor tubukilota (A) & Leaf & $\begin{array}{l}\text { TG 1092; TG } \\
1149\end{array}$ & $\begin{array}{l}\text { Saikia et al. 2007; Das et al. 2012; Bhuyan and Baishya } \\
\text { 2013; Handique and Deka 2016; Senapati and } \\
\text { Gurumayum 2016; Nath et al. } 2019\end{array}$ \\
\hline $\mathrm{Ah}$ & Citrus $\times$ limon $($ L.) Osbeck & Rutaceae & Nemutenga (A) & Leaf & TG 1094 & - \\
\hline $\mathrm{Ah}, \mathrm{Mi}$ & Clematis apiifolia DC. & Ranunculaceae & $\begin{array}{l}\text { Horusoi/ Horugoropsoi (A), } \\
\text { Ramnam bon (M) }\end{array}$ & Leaf & $\begin{array}{l}\text { CM 117; TG } \\
1150\end{array}$ & - \\
\hline $\mathrm{Ah}$ & Clematis zeylanica (L.) Poir. & Ranunculaceae & $\begin{array}{l}\text { Gop-sori/Soi pan/ Gorobsoi } \\
\text { (A) }\end{array}$ & Leaf & $\begin{array}{l}\text { PB 1027; TG } \\
1119\end{array}$ & $\begin{array}{l}\text { Deori et al. 2007; Baruah et al. 2010; Kardong et al. } \\
\text { 2012; Bhuyan and Baishya 2013; Gogoi et al. 2013; } \\
\text { Handique and Deka 2016 Senapati and Gurumayum } \\
\text { 2016; Bhuyan and Rajak 2019; Nath et al. 2019; }\end{array}$ \\
\hline Ah, Bo & $\begin{array}{l}\text { Clerodendrum colebrookeanum } \\
\text { Walp. }\end{array}$ & Lamiaceae & Nefafu (A), Mwkhwna (B) & Leaf & $\begin{array}{l}\text { JB } 024 ; \text { PB 1038; } \\
\text { JS } 2345\end{array}$ & - \\
\hline $\begin{array}{l}\mathrm{Ah}, \mathrm{Bo}, \mathrm{Ga}, \\
\mathrm{Mi}\end{array}$ & Clerodendrum infortunatum $\mathrm{L}$. & Lamiaceae & $\begin{array}{l}\text { Dhopattita (A), Pakkom } \\
\text { (M), Samaki (G) }\end{array}$ & Leaf & $\begin{array}{l}\text { JS 001; JS 012; } \\
\text { TG } 1095\end{array}$ & $\begin{array}{l}\text { Tanti et al. 2008; Baruah et al. 2010; Deka and Sarma } \\
\text { 2010; Das et al. 2012; Bhuyan and Baishya 2013; Gogoi } \\
\text { et al. 2013; Pawe and Gogoi 2013; Basumatary et al. } \\
\text { 2014; Basumatary and Gogoi 2014; Brahma et al. 2014; } \\
\text { Das 2016; Handique and Deka 2016; Senapati and } \\
\text { Gurumayum 2016; Bhuyan and Rajak 2019; Nath et al. } \\
2019\end{array}$ \\
\hline $\mathrm{Ah}$ & Commelina benghalensis L. & Commelinaceae & Kona himolu (A) & Leaf & PB 1046 & - \\
\hline $\mathrm{Ah}$ & Cordyline fruticosa (L.) A.Chev. & Asparagaceae & Panormahi (A) & Leaf & TG 1151 & - \\
\hline Mi & Coriandrum sativum $\mathrm{L}$. & Apiaceae & Dhania (M) & Twig & JS 002 & - \\
\hline $\mathrm{Ah}$ & $\begin{array}{l}\text { Crassocephalum crepidioides } \\
\text { (Benth.) S.Moore }\end{array}$ & Asteraceae & Bon kopahi (A) & Leaf & TG 1152 & - \\
\hline $\mathrm{Ah}$ & Croton caudatus Geiseler & Euphorbiaceae & Lotamahudi/Mahudi (A) & Leaf & $\begin{array}{l}\text { BG 005; PB } \\
\text { 1042; TG } 1096\end{array}$ & Senapati and Gurumayum 2016; Nath et al. 2019 \\
\hline $\mathrm{Ah}, \mathrm{Ka}$ & Croton joufra Roxb. & Euphorbiaceae & $\begin{array}{l}\text { Gochmahudi (A), Marthu } \\
\text { (K) }\end{array}$ & Leaf & $\begin{array}{l}\text { DB1067; TG } \\
1097\end{array}$ & $\begin{array}{l}\text { Teron 2006; Baruah et al. 2010; Bhuyan and Baishya } \\
\text { 2013; Senapati and Gurumayum } 2016\end{array}$ \\
\hline $\mathrm{Ah}$ & Curcuma longa $\mathrm{L}$. & Zingiberaceae & Halodhi (A) & Leaf & TG 1098 & Das 2016; Bhuyan and Rajak 2019 \\
\hline $\mathrm{Mi}$ & Cuscuta reflexa Roxb. & Convolvulaceae & Rabonlota (M) & Root & JS 004 & - \\
\hline $\mathrm{Ah}$ & Cyanthillium cinereum (L.) H.Rob. & Asteraceae & Hohodevi bon (A) & Leaf & TG 1099 & - \\
\hline $\mathrm{Ah}$ & Cynodon dactylon (L.) Pers. & Poaceae & Dubori bon $(\mathrm{A})$ & Leaf & PB 1031 & - \\
\hline $\mathrm{Ah}$ & $\begin{array}{l}\text { Cyperus mindorensis (Steud.) } \\
\text { Huygh }\end{array}$ & Cyperaceae & Keya bon (A) & Leaf & PB 1048 & - \\
\hline
\end{tabular}




\begin{tabular}{|c|c|c|c|c|c|c|}
\hline 2028 & & & IODIVERSITAS 22 (4): & -2031 & pril 2021 & \\
\hline $\mathrm{Ah}$ & Desmodium sp. & Fabaceae & Bionihabota (A) & Leaf & $\begin{array}{l}\text { PB 1033; TG } \\
1101\end{array}$ & - \\
\hline $\mathrm{Ah}, \mathrm{Mi}$ & $\begin{array}{l}\text { Drymaria cordata (L.) Willd. } \\
\text { exSchult. }\end{array}$ & Caryophyllaceae & $\begin{array}{l}\text { Lai jabori (A), Dobag/ } \\
\text { porog-tape }(\mathrm{M})\end{array}$ & $\begin{array}{l}\text { Leaf, } \\
\text { Twig }\end{array}$ & $\begin{array}{l}\text { PB 1051; CM } \\
112 ; \text { TG } 1102\end{array}$ & $\begin{array}{l}\text { Baruah et al. 2010; Das et al. 2012; Gogoi et al. 2013; } \\
\text { Senapati and Gurumayum 2016; Bhuyan and Rajak } 2019\end{array}$ \\
\hline $\mathrm{Ah}$ & Eclipta prostrata (L.) L. & Asteraceae & Kehraj (A) & Leaf & PB 1054 & - \\
\hline $\mathrm{Ah}$ & Eryngium foetidum $\mathrm{L}$. & Apiaceae & Maandhania (A) & Leaf & PB 1075 & - \\
\hline $\mathrm{Ah}$ & Ethulia conyzoides L. & Asteraceae & Bon-jira (A) & Leaf & TG1908 & - \\
\hline $\mathrm{Ah}$ & Eurya acuminata DC. & $\begin{array}{l}\text { Pentaphylacacea } \\
\text { e }\end{array}$ & Murmuri pat (A) & Leaf & TG 1103 & - \\
\hline $\mathrm{Ah}, \mathrm{Mi}$ & $\begin{array}{l}\text { Flemingia strobilifera }(\mathrm{L} .) \\
\text { W.T.Aiton }\end{array}$ & Fabaceae & Makhioti (A, M) & Leaf & $\begin{array}{l}\text { JS 005; PB 1035; } \\
\text { TG } 1104\end{array}$ & - \\
\hline $\mathrm{Ah}$ & $\begin{array}{l}\text { Glochidion zeylanicum var. } \\
\text { Tomentosum (Dalzell) Trimen }\end{array}$ & Phyllanthaceae & Pani madhuri (A) & Leaf & TG 1105 & - \\
\hline $\mathrm{Ah}$ & Grewia serrulata DC. & Malvaceae & Kukurhuta (A) & Leaf & TG 1106 & - \\
\hline $\mathrm{Ah}$ & $\begin{array}{l}\text { Grona triflora }(\mathrm{L} .) \\
\text { H.Ohashi\&K.Ohashi }\end{array}$ & Fabaceae & Goyona bon (A) & Leaf & TG 1153 & - \\
\hline Mi & $\begin{array}{l}\text { Hellenia speciosa (J.Koenig) } \\
\text { S.R.Dutta }\end{array}$ & Costaceae & Jomlakhuti (M) & Leaf & JS 003 & $\begin{array}{l}\text { Deori et al. 2007; Das et al. 2012; Kardong et al. 2012; } \\
\text { Gogoi et al. 2013; Pawe and Gogoi 2013; Senapati and } \\
\text { Gurumayum 2016; Bhuyan and Rajak } 2019\end{array}$ \\
\hline $\mathrm{Ah}, \mathrm{Mi}$ & Hibiscus rosa-sinensis $\mathrm{L}$. & Malvaceae & Leunaapum (M), Joba (A) & Leaf & JS 006; PB 1060 & $e^{2}$ \\
\hline $\mathrm{Ah}$ & Hydrocotyle sibthorpioides Lam. & Araliaceae & Horumani-muni (A) & $\begin{array}{l}\text { Whole } \\
\text { plant }\end{array}$ & $\begin{array}{l}\text { BG 008; PB } \\
\text { 1034; TG } 1107\end{array}$ & $\begin{array}{l}\text { Baruah et al. 2010; Das et al. 2012; Kardong et al. 2012; } \\
\text { Bhuyan and Baishya 2013; Handique and Deka 2016; } \\
\text { Senapati and Gurumayum 2016; Bhuyan and Rajak 2019; } \\
\text { Nath et al. 2019; }\end{array}$ \\
\hline $\mathrm{Ah}$ & Ixora polyantha Wight & Rubiaceae & $\begin{array}{l}\text { Dhepaijamu/Matikathalua } \\
\text { (A) }\end{array}$ & Leaf & TG 1154 & - \\
\hline $\mathrm{Ah}$ & Jasminum sp. & Oleaceae & Duamali (A) & Leaf & BG 009 & - \\
\hline $\mathrm{Ah}$ & Leea indica (Burm.f.) Merr. & Vitaceae & Kukurathengia (A) & Leaf & PB 1072 & - \\
\hline Ah, Bo & Leucas aspera (Willd.) Link & Lamiaceae & $\begin{array}{l}\text { Durun bon (A), Khansisa } \\
\text { (B) }\end{array}$ & Leaf & $\begin{array}{l}\text { PB 1037; JB 025; } \\
\text { TG } 1108\end{array}$ & $\begin{array}{l}\text { Saikia et al. 2007; Das et al. 2012; Pawe and Gogoi 2013; } \\
\text { Gogoi et al. 2013; Das 2016; Handique and Deka 2016; } \\
\text { Senapati and Gurumayum 2016; Bhuyan and Rajak 2019; } \\
\text { Goswami } 2020\end{array}$ \\
\hline Mi & $\begin{array}{l}\text { Lippia alba (Mill.) N.E.Br. ex } \\
\text { Britton \&P.Wilson }\end{array}$ & Verbenaceae & Pohukata (M) & $\begin{array}{l}\text { Leaf, } \\
\text { Flowe } \\
\mathrm{r}\end{array}$ & JS 007 & - \\
\hline $\mathrm{Ah}$ & Litsea glutinosa (Lour.) C.B.Rob. & Lauraceae & Ganhualu (A) & Leaf & TG 1109 & - \\
\hline $\mathrm{Mi}$ & Litsea monopetala (Roxb.) Pers. & Lauraceae & Tapid (M) & Leaf & CM 116 & - \\
\hline $\mathrm{Ah}$ & $\begin{array}{l}\text { Litsea nitida (Roxb. ex Nees) } \\
\text { Hook.f. }\end{array}$ & Lauraceae & Kothlua pat (A) & Leaf & TG 1110 & - \\
\hline $\mathrm{Ah}$ & $\begin{array}{l}\text { Litsea salicifolia (Roxb. ex Nees) } \\
\text { Hook.f. }\end{array}$ & Lauraceae & Dighloti pat (A) & Leaf & TG 1111 & - \\
\hline $\mathrm{Ah}, \mathrm{Mi}$ & Lygodium flexuosum (L.) Sw. & Lygodiaceae & $\begin{array}{l}\text { Kapau-dhekia (A), } \\
\text { Tisurkosang (M) }\end{array}$ & Twig & $\begin{array}{l}\text { BG 010; PB } \\
1021 ; \text { CM 113; } \\
\text { TG } 1112\end{array}$ & $\begin{array}{l}\text { Deori et al. 2007; Saikia et al. 2007; Baruah et al. 2010; } \\
\text { Das et al. 2012; Bhuyan and Baishya 2013; Gogoi et al. } \\
\text { 2013; Pawe and Gogoi 2013; Handique and Deka 2016; } \\
\text { Senapati and Gurumayum 2016; Bhuyan and Rajak 2019; }\end{array}$ \\
\hline
\end{tabular}




\begin{tabular}{|c|c|c|c|c|c|c|}
\hline & & & & & & Nath et al. 2019 \\
\hline $\mathrm{Ah}$ & Macaranga indica Wight & Euphorbiaceae & Sikamorolia pat (A) & Leaf & TG 1114 & - \\
\hline $\mathrm{Ah}$ & Maesa chisia D.Don & Primulaceae & Rajmoni (A) & Leaf & TG 1155 & - \\
\hline $\mathrm{Ah}$ & Maesa indica (Roxb.) Sweet & Primulaceae & $\begin{array}{l}\text { Ouwapat/Maspua/ } \\
\text { Checuriya (A) }\end{array}$ & Leaf & TG 1156 & - \\
\hline $\mathrm{Ah}$ & Melastoma malabathricum $\mathrm{L}$. & $\begin{array}{l}\text { Melastomatacea } \\
\mathrm{e}\end{array}$ & Phutkola (A) & Leaf & $\begin{array}{l}\text { PB 1040; TG } \\
1115\end{array}$ & $\begin{array}{l}\text { Deori et al. 2007; Senapati and Gurumayum 2016; } \\
\text { Bhuyan and Rajak } 2019\end{array}$ \\
\hline $\mathrm{Ah}$ & Mesua ferrea $\mathrm{L}$. & Calophyllaceae & Nahor (A) & Leaf & TG 1157 & - \\
\hline $\mathrm{Ah}$ & Mimosa pudica $\mathrm{L}$. & Fabaceae & Lajuki bon (A) & Leaf & $\begin{array}{l}\text { PB 1062; TG } \\
1116\end{array}$ & - \\
\hline $\mathrm{Ah}$ & Morinda angustifolia Roxb. & Rubiaceae & $\begin{array}{l}\text { Aasugoch, Daruhoridra pat } \\
\text { (A) }\end{array}$ & $\begin{array}{l}\text { Leaf, } \\
\text { Root }\end{array}$ & TG 1117 & - \\
\hline $\mathrm{Ah}$ & Morus rubra $\mathrm{L}$. & Moraceae & Nuni (A) & Leaf & PB 1061 & - \\
\hline $\mathrm{Ah}$ & Murraya koenigii (L.) Spreng. & Rutaceae & Norohingha (A) & Leaf & PB 1045 & - \\
\hline $\mathrm{Ah}, \mathrm{Bo}$ & Musa balbisiana Colla & Musaceae & Bhimkol (A) & Leaf & TG 1118 & - \\
\hline $\mathrm{Ah}, \mathrm{Bo}$ & Mussaenda roxburghii Hook.f. & Rubiaceae & $\begin{array}{l}\text { Naga bali/Sorairatha }(\mathrm{A}) \text {, } \\
\text { Bose (B) }\end{array}$ & Leaf & JB 026; TG 1158 & $\begin{array}{l}\text { Gogoi et al. 2013; Das and Hazarika 2015; Basumatary } \\
\text { and Gogoi 2014; Senapati and Gurumayum } 2016\end{array}$ \\
\hline $\mathrm{Ah}$ & Nelsonia canescens (Lam.) Spreng. & Acanthaceae & Udbhedeli/Baghkaniya (A) & Leaf & TG 1159 & $\begin{array}{l}\text { Deori et al. 2007; Senapati and Gurumayum 2016; } \\
\text { Bhuyan and Rajak } 2019\end{array}$ \\
\hline $\mathrm{Ah}$ & Olax acuminata Wall. ex Benth. & Olacaceae & Kopohua (A) & Leaf & TG 1120 & Bhuyan and Rajak 2019 \\
\hline $\mathrm{Ah}$ & Oldenlandia corymbosa $\mathrm{L}$. & Rubiaceae & Bon jaluk (A) & $\begin{array}{l}\text { Whole } \\
\text { plant, } \\
\text { Leaf }\end{array}$ & $\begin{array}{l}\text { BG 011; PB } \\
1026 ; \text { TG } 1121\end{array}$ & $\begin{array}{l}\text { Baruah et al. 2010; Das et al. 2012; Gogoi et al. 2013; } \\
\text { Pawe and Gogoi 2013; Senapati and Gurumayum 2016; } \\
\text { Handique and Deka 2016; Bhuyan and Rajak } 2019\end{array}$ \\
\hline $\mathrm{Ah}$ & Ophiorrhiza sp. & Rubiaceae & $\begin{array}{l}\text { Nakulastha/Harpo } \\
\text { shree/Matirahipora (A) }\end{array}$ & Leaf & TG 1160 & - \\
\hline $\mathrm{Ah}$ & Oryza sativa $\mathrm{L}$. & Poaceae & Dhan (A) & Seed & BG 012 & $\begin{array}{l}\text { Deori et al. 2007; Baruah et al. 2010; Gogoi et al. 2013; } \\
\text { Bhuyan and Baishya 2013; Basumatary et al. 2014; } \\
\text { Basumatary and Gogoi 2014; Senapati and Gurumayum } \\
\text { 2016; Bhuyan and Rajak 2019; Nath et al. } 2019\end{array}$ \\
\hline $\mathrm{Ah}$ & Oxalis debilis Kunth & Oxalidaceae & Tengesi (A) & Leaf & PB 1052 & \\
\hline $\mathrm{Ah}$ & Peperomia pellucida (L.) Kunth & Piperaceae & Panounua (A) & Leaf & PB 1050 & - \\
\hline $\mathrm{Ah}$ & Persicaria chinensis (L.) H.Gross & Polygonaceae & Madhuhuleng (A) & Leaf & PB 1070 & - \\
\hline Bo & $\begin{array}{l}\text { Persicaria glabra (Willd.) } \\
\text { M.Gomez }\end{array}$ & Polygonaceae & Bisongali (B) & Leaf & JS 2347 & - \\
\hline $\mathrm{Ah}, \mathrm{Mi}$ & $\begin{array}{l}\text { Persicaria hydropiper }(\mathrm{L} .) \\
\text { Delarbre }\end{array}$ & Polygonaceae & $\begin{array}{l}\text { Leubo (M), } \\
\text { Pothoruabihlongani (A) }\end{array}$ & Twig & JS 009; TG 1127 & Das and Hazarika 2015 \\
\hline Mi & $\begin{array}{l}\text { Persicaria microcephala (D.Don) } \\
\text { H.Gross }\end{array}$ & Polygonaceae & Nekungkune (M) & Leaf & JS 010 & - \\
\hline $\mathrm{Ah}$ & Persicaria perfoliata (L.) H.Gross & Polygonaceae & Baghaasur/ Baghasura (A) & Leaf & $\begin{array}{l}\text { PB 1069; TG } \\
1122\end{array}$ & - \\
\hline $\mathrm{Ah}$ & Phyllanthus fraternus G.L.Webster & Phyllanthaceae & Bon aamlokhi (A) & Leaf & PB 1044 & - \\
\hline $\mathrm{Ah}$ & Physalis angulata $\mathrm{L}$. & Solanaceae & Pokmou (A) & Leaf & PB 1076 & - \\
\hline $\mathrm{Ah}, \mathrm{Mi}$ & Piper betle L. & Piperaceae & Paan (M) & Leaf & $\begin{array}{l}\text { CM 110; TG } \\
1123\end{array}$ & $\begin{array}{l}\text { Saikia et al. 2007; Das et al. 2012; Arjun et al. 2014; } \\
\text { Bhuyan and Rajak } 2019\end{array}$ \\
\hline $\mathrm{Ah}$ & Piper longum $\mathrm{L}$. & Piperaceae & Pipolee (A) & Leaf & TG 1124 & Kardong et al. 2012; Pawe and Gogoi 2013; Das and \\
\hline
\end{tabular}


Hazarika 2015; Senapati and Gurumayum 2016; Bhuyan and Rajak 2019

Piper nigrum $\mathrm{L}$.

Piper sp.

Plantago asiatica $\mathrm{L}$

Plumbago zeylanica $\mathrm{L}$.

Pogostemon benghalensis

(Burm.f.) Kuntze

Potentilla indica (Andrews)

Th. Wolf

Ah

Pouzolzia zeylanica (L.) Benn

Pseuderanthemum latifolium

(Vahl) B.Hansen

Ah, Mi

Psidium guajava $\mathrm{L}$.

$\begin{array}{ll}\text { Ah } & \text { Psychotria sp. } \\ \text { Ah } & \begin{array}{l}\text { Rotheca serrata }(\text { L.) Steane \& } \\ \text { Mabb. }\end{array} \\ \text { Ah } & \begin{array}{l}\text { Rubus moluccanus } \text { L. } \\ \text { Ah }\end{array} \\ \text { Ah, Bo } & \begin{array}{l}\text { Rumex maritimus } \text { L. } \\ \text { Saccharum officinarum } \text { L. }\end{array}\end{array}$

Rubiaceae

Lamiaceae

Rosaceae

Polygonaceae

Poaceae

Ah, Bo, Mi Scoparia dulcis L.

Plantaginaceae

\section{Senibon/Senigutigoch/Bon tulokhi/Modhumehari (A) Jaluk bon (M),}

Selaginellaceae

Malvaceae

Smilacaceae

Smilax ovalifolia Roxb. ex D.Don

Sohmaea laxiflora (DC.) H.Ohashi Fabaceae

\& K.Ohashi
Dongfangrakheb (B)

Khunkhunidhekia (A)

Hoonbarial (A)

Tikonibaruah (A)

$\begin{array}{ll}\text { Leaf } & \text { PB 1025; TG } \\ & \text { 1125 } \\ \text { Leaf } & \text { TG } 1126 \\ \text { Leaf } & \text { TG 1161 } \\ \text { Leaf } & \text { JS } 011\end{array}$

Leaf PB 1063

Leaf PB 1058

Leaf PB 1047

Leaf TG 1162

Leaf PB 1041; TG 1128

Leaf BG 001; PB

1023; TG 1163

1023; TG

Leaf PB 1036; TG

1130

Leaf TG 1131

Leaf JB 023; TG 1165

Leaf, BG 014; PB

Young 1022; JB 022.

shoot CM 112; JS

2348; TG 1132

Beoni-

haputa/Beonihabota/Ulutak

Leaf PB 1028; TG

1134
CM 107; BG 013

Basumatary and Gogoi 2014; Basumatary et al. 2014;

Deori et al. 2007; Baruah et al. 2010; Deka and Sarma 2010; Das et al. 2012; Pawe and Gogoi 2013; Bhuyan and Baishya 2013; Gogoi et al. 2013; Das and Hazarika 2015; Senapati and Gurumayum 2016; Das 2016;

Bhuyan and Rajak 2019; Goswami 2020

Das 2016

Bhuyan and Rajak 2019

Deori et al. 2007; Baruah et al. 2010; Pawe and Gogoi 2013; Gogoi et al. 2013; Das and Hazarika 2015;

Senapati and Gurumayum 2016; Bhuyan and Rajak 2019 Deori et al. 2007; Saikia et al. 2007; Baruah et al. 2010;

Deka and Sarma 2010; Kardong et al. 2012; Das et al.

2012; Pawe and Gogoi 2013; Gogoi et al. 2013; Bhuyan and Baishya 2013; Basumatary et al. 2014; Basumatary and Gogoi 2014; Brahma et al. 2014; Senapati and

Gurumayum 2016; Das 2016; Handique and Deka 2016; Bhuyan and Rajak 2019

Bhuyan and Baishya 2013; Senapati and Gurumayum 2016; Nath et al. 2019

Leaf BG 007; TG 1166 Baruah et al. 2010
Senapati and Gurumayum 2016; Bhuyan and Rajak 2019 
BORAH et al. - Compendium of plants used for preparation of traditional alcoholic beverages

\begin{tabular}{|c|c|c|c|c|c|c|}
\hline & & & & & & \\
\hline $\mathrm{Ah}$ & Solanum americanum Mill. & Solanaceae & Loskosi (A) & Leaf & PB 1055 & - \\
\hline $\mathrm{Ah}$ & Solanum nigrum $\mathrm{L}$. & Solanaceae & Bhekuri (A) & Leaf & PB 1065 & - \\
\hline $\mathrm{Ah}$ & Solena heterophylla Lour. & Cucurbitaceae & Belipoka, Ghukusmoi (A) & Leaf & TG 1167 & $\begin{array}{l}\text { Kardong et al. 2012; Gogoi et al. 2013; Pawe and Gogoi } \\
\text { 2013; Senapati and Gurumayum } 2016\end{array}$ \\
\hline $\mathrm{Ah}$ & Sphagneticola trilobata (L.) Pruski & Asteraceae & Bhringraj (A) & Leaf & TG 1135 & - \\
\hline $\mathrm{Ah}$ & Spondias pinnata (L.f.) Kurz & Anacardiaceae & Omora (A) & Leaf & PB 1067 & - \\
\hline $\mathrm{Ah}$ & Stellaria media (L.) Vill. & Caryophyllaceae & Morolia (A) & Leaf & PB 1049 & - \\
\hline $\mathrm{Ah}$ & $\begin{array}{l}\text { Stenochlaena palustris (Burm.f.) } \\
\text { Bedd. }\end{array}$ & Aspleniaceae & Dhekia loti (A) & Leaf & $\begin{array}{l}\text { PB 1032; TG } \\
1136\end{array}$ & - \\
\hline $\mathrm{Ah}, \mathrm{Mi}$ & Stephania rotunda Lour. & Menispermaceae & $\begin{array}{l}\text { Hortubukilota/Tubukilota } \\
\text { (A), Nginti (M) }\end{array}$ & Leaf & $\begin{array}{l}\text { PB 1024; CM } \\
114 ; \text { TG } 1093\end{array}$ & - \\
\hline $\mathrm{Ah}$ & Stixissuaveolens (Roxb.) Baill. & Resedaceae & Madhoimalati (A) & $\begin{array}{l}\text { Leaf, } \\
\text { Root }\end{array}$ & TG 1129 & - \\
\hline $\mathrm{Ah}$ & Streblus asper Lour. & Moraceae & Houra pat (A) & Leaf & TG 1137 & Das 2016; Goswami 2020 \\
\hline Ah & Tetracera sarmentosa (L.) Vahl & Dilleniaceae & Ou lata (A) & Leaf & TG 1168 & - \\
\hline $\begin{array}{l}\mathrm{Ah}, \mathrm{Bo}, \mathrm{Mi}, \\
\mathrm{Ga}\end{array}$ & Thelypteris parasitica (L.) Tardieu & Aspleniaceae & $\begin{array}{l}\text { Bihlongoni (A), Sarath }(\mathrm{G}) \\
\text { Dingkhia (B) }\end{array}$ & Frond & $\begin{array}{l}\text { PB 1029; BG } \\
\text { 006; JS 013; JB } \\
\text { 028; TG 1081; } \\
\text { CM } 109\end{array}$ & Pawe and Gogoi 2013 \\
\hline $\mathrm{Ah}$ & $\begin{array}{l}\text { Thunbergia grandiflora (Roxb. ex } \\
\text { Rottler) Roxb. }\end{array}$ & Acanthaceae & $\begin{array}{l}\text { Hetaloti/Kauri thutialota } \\
\text { (A) }\end{array}$ & Leaf & TG 1139 & - \\
\hline Ah, Mi & $\begin{array}{l}\text { Tinospora cordifolia (Willd.) } \\
\text { Hook.f. \& Thomson }\end{array}$ & Menispermaceae & Amrita (M), Hogunilota (A) & Leaf & JS 008; PB 1064 & - \\
\hline $\mathrm{Ah}$ & Vitex negundo $\mathrm{L}$. & Lamiaceae & Posotia (A) & Leaf & PB 1066 & Senapati and Gurumayum 2016 \\
\hline $\mathrm{Ah}$ & Zanthoxylum nitidum (Roxb.) DC. & Rutaceae & Tezmui/Tezmoori (A) & $\begin{array}{l}\text { Leaf, } \\
\text { Root }\end{array}$ & BG 015; TG 1140 & $\begin{array}{l}\text { Tanti et al. 2008; Baruah et al. 2010; Kardong et al. 2012; } \\
\text { Pawe and Gogoi 2013; Senapati and Gurumayum 2016; } \\
\text { Handique and Deka 2016; Bhuyan and Rajak } 2019\end{array}$ \\
\hline $\mathrm{Ah}$ & Zingiber officinale Roscoe & Zingiberaceae & Ada (A) & Leaf & TG 1141 & $\begin{array}{l}\text { Deori et al. 2007; Pawe and Gogoi 2013; Senapatiaand } \\
\text { Gurumayum 2016; Bhuyan and Rajak } 2019\end{array}$ \\
\hline
\end{tabular}

